Ann. Zootech., I97I, 20 (4), 55I-575.

\title{
LE DÉVELOPPEMENT DES ENZYMES DANS LE TUBE DIGESTIF DU JEUNE PORCELET : IMPORTANCE POUR LE SEVRAGE ET SIGNIFICATION NUTRITIONNELLE ( $\left.{ }^{1}\right)$
}

\author{
A. AUMAITRE \\ avec la collaboration technique de P. VAISSADE \\ Station de Recherches sur l'Élevage des Porcs, \\ Centre national de Recherches zootechniques, $I . N . R$. A., \\ 78 - Jouy-en-Josas
}

\section{PLAN}

INTRODUCTION.

I. - LES ENZyMES DIGESTIVES DU PORCElet.

I. I. Les enzymes lipolytiques.

I. I. I. La lipase chez le monogastrique.

I. I. 2. Influence de l'âge sur l'activité lipasique.

I. I. 3. Variation du taux de lipase suivant la composition du régime.

1. 2. Les enzymes protéolytiques.

I. 2. I. Les enzymes protéolytiques du tube digestif chez le jeune.

I. 2. 2. Développement de l'activité protéolytique du porcelet avec l'âge.

I. 2. 3. Développement de l'activité protéolytique et composition du régime alimentaire.

I. 3. Les enzymes glucolytiques.

I. 3. I. Multiplicité des enzymes glucolytiques chez le porcelet.

I. 3. 2. Développement des enzymes avec l'âge.

- Amylase

- Maltases, lactase, invertase.

r. 3. 3. Adaptation suivant la nature du régime du porcelet.

2. - Importance des enzymes dans la digestion chez le monogastrique.

2. I. Rôle des enzymes dans la digestion.

2. r. I. Digestion des lipides.

2. I. 2. Digestion enzymatique des protéines chez le porcelet.

(1) Revue bibliographique et travaux personnels présentés au Congrès de Ia F. E. Z. Commission de Production porcine (I969) (Helsinki). 


\section{A. AUMAITRE}

2. I. 3. Digestion des glucides chez le porcelet.

2. 2. Conséquences physio-pathologiques du manque d'enzymes chez le nourrisson.

3. - Signification Nutritionnelle de l'adaptation Des enzymes digestives du Jeune : LE SEVRAGE.

3. I. Tolérance des aliments par le jeune.

3. 2. Évolution de la digestibilité des éléments de la ration avec l'âge.

3. 2. I. Effet de la nature des protéines sur leur digestibilité.

3. 2. 2. Effet de la nature des glucides sur leur digestibilité.

3. 3. Limites de nos conceptions sur le rôle des enzymes dans les phénomènes de digestion chez le porcelet.

3. 3. I. Supplémentation des rations en enzymes.

3. 3. 2. Origine de l'amidon et ses traitements technologiques.

3. 4. Conséquences pour le sevrage des animaux.

\section{Conclusions.}

RÉFÉRENCES BIBLIOGRAPHIQUES.

\section{RÉSUMÉ}

Le développenıent physiologique du tube digestif du porcelet allaité ou en cours de sevrage a été largement étudié au cours des 15 dernières années.

Les enzymes digestives, et leur développement avec l'âge, ont fait l'objet de nombreuses études analytiques surtout consacrées aux cnzymes glucolytiques et protéolytiques. C'est au cours des années récentes que l'cn a émis l'hypothèse, puis démontré l'adaptation de ces enzymes avec la nature du régime du jeune animal sous la mère ct en cours de sevrage.

Après avoir fait le point de nos connaissances sur le développement des enzymes, nous avons schématisé leur rôle fondamental dans les processus de digestion et dans la nutrition du jeune en signalant l'effet néfaste d'un manque d'enzymes ou d'un manque d'aclaptation sur le fonctionnement normal du tube digestif.

Des conclusions sont ensuite tirées sur la signification du développement des enzymes dans la physiologie du jeune et sur la détermination d'un àge optimal au sevrage basé sur les connaissances des processus enzymatiques de la digestion.

\section{INTRODUCTION}

C'est au cours du xvir ${ }^{e}$ siècle que les travaux historiques de RFAUmer et SPAIIANZANI ont attiré l'attention sur le rôle fondamental des sécrétions internes cu tube digestif dans la digestion des aliments. I)epuis, de nombreux travaux ont été consacrés à la compréhension du mécanisme d'action des différentes enzymes, de leur spécificité vis-à-vis des substrats nutritionnels, de leur variété entre les différentes espèces animales mais aussi cle leur présence ou de leur absence clans le tube digestif des monogastriques à certains stades de leur vie. 
Mais, ce n'est qu'à partir de $195^{\circ}$ que les expériences réalisées sur le sevrage précoce ont permis de mettre en évidence la présence des enzymes chez le Porcelet nouveau-né, leur développement avec l'âge et leur rôle particulier dans la physiologie nutritionnelle au moment du sevrage (LEWIS et al., I957 ; WALKER, I959; HARTMAN et al., I961).

Dans les conditions pratiques d'élevage, les jeunes porcelets sont allaités pendant un temps plus ou moins long, mais les nécessités économiques ont conduit les zootechniciens à accélérer la séparation des jeunes animaux de leur mère et à les préparer à la nourriture principalement glucidique de l'adulte.

A la suite d'intolérances classiques à certains glucides, l'accent a été particulièrement mis sur la nécessité de la présence de certaines enzymes glucolytiques dans le tube digestif du jeune avant son sevrage (Dolrar et al., I957; Cunningham, I959).

Le sevrage constitue en effet un changement important dans la nature des constituants de la ration (fig. I). La source énergétique principale du porcelet sous

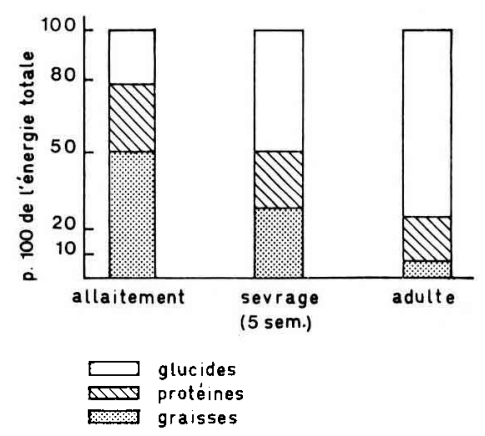

FIG. I. - Variation avec l'âge de la composition de l'aliment du Porc: nature de l'énergie

la mère est fournie au début de sa vie par les lipides, puis les glucides deviennent de plus en plus importants lorsque l'animal vieillit et reçoit une ration comparable à celle de l'adulte. De même, un changement de la nature, de la structure physique des protéines alimentaires s'opère en même temps : les protéines du lait sont peu à peu remplacées par des protéines d'origine végétale.

Les phénomènes physiologiques de la digestion sont profondément modifiés au cours de cette période (MANER et al., I962), évoluant d'une part de la digestion du lactose à la digestion beaucoup plus complexe de l'amidon, d'autre part de la digestion principalement stomacale des protéines du lait (albumine, globuline, caséine) à la digestion surtout intestinale des protéines des tourteaux (PEKAS et al., 1964).

C'est une revue de nos connaissances actuelles, à travers les travaux les plus récents sur la digestion enzymatique chez le Porcelet et son évolution depuis la naissance jusqu'au sevrage, que nous avons entreprise. Nous essaierons à l'aide de quelques exemples, de schématiser les différents phénomènes, d'en montrer la complexité, mais surtout d'en dégager les incidences et les conséquences en vue de raisonner le sevrage du porcelet sur des bases physiologiques. 


\section{I. - LES ENZYMES DIGESTIVES DU PORCELET}

\section{I. - Les enzymes lipolytiques}

On distingue plusieurs types d'hydrolases qui assurent la digestion des lipides et dont l'activité est souvent exprimée globalement chez le Porcelet, la lipase proprement dite dégradant les triglycérides et les estérases plus ou moins spécifiques des lipides complexes.

\section{I. I. La lipase chez le monogastrique.}

La lipase assure la digestion des graisses du lait, principale source d'énergie au début de la vie du jeune. Son origine est presque exclusivement pancréatique (KITTs et al., I956; HARTMAN et al., I96I ; PEKAs, I96I). RAMSEy et al. (I960) signalent la présence d'une activité estérasique dans l'estomac du jeune veau allaité, alors que chez le Porcelet, aucune activité de ce type n'a pu être mise en évidence.

Bien que les valeurs trouvées soient variables entre les échantillons, le suc pancréatique du porcelet possède une activité lipasique importante et le pancréas exporte de grandes quantités journalières d'enzymes lipolytiques (tabl. I).

\section{TABLEAU I}

Activité enzymatique du suc pancréatique du porcelet au sevrage (3o jours) (Aumaitre et RÉrat, I966)

\begin{tabular}{|c|c|c|c|c|}
\hline \multirow{2}{*}{ Enzymes } & \multicolumn{2}{|c|}{ Activité/ml } & \multicolumn{2}{|c|}{ Activité spécifique $\left({ }^{4}\right)$} \\
\hline & Moyenne & Extrêmes $\left({ }^{1}\right)$ & Moyenne & Extrêmes \\
\hline Amylase ( ${ }^{\mathbf{2}}$ ) & 850 & $300-1800$ & 300 & $189-485$ \\
\hline Lipase $\left({ }^{3}\right)$. & 1. 150 & $380-4500$ & 195 & $134-284$ \\
\hline Chymotrypsine $\left({ }^{3}\right)$ & 248 & $130-352$ & 42 & $31-51$ \\
\hline Trypsine $\left(^{3}\right) \ldots \ldots$ & 52 & $34-138$ & 10 & $3,8-1 / 4$ \\
\hline
\end{tabular}

(1) Entre porcelets du même poids/âge (moyenne de 10 animaux sur 10 échantillons).

( $\left.{ }^{2}\right) \mathrm{mg}$ maltose/20 minutes.

( $\left.{ }^{3}\right)$ moles de substrat hydrolysé/minute.

(4) Activité par mg de protéines du suc.

\section{I 2. Influence de l'âge sur l'activité lipasique.}

A partir de quelques études réalisées sur le pancréas du porcelet, sacrifié à différents âges, on peut affirmer :

- que l'activité de la lipase au niveau du pancréas, mesurée in vitro, est très importante dès la naissance,

- cette activité augmente légèrement avec 1'âge (KITTS et al., I956; HARTMAN et al., I96I) chez le Porcelet et reste encore très élevée chez l'animal adulte. 
L,es études effectuées sur d'autres espèces monogastriques et notamment le Rat, par KoldDovsky (I966) et CoRring et Aumaitre (I970) confirment cette légère augmentation avec l'âge pendant la période d'allaitement et en particulier une activité élevée au moment du sevrage. Elles précisent même 1'existence de quantités importantes de lipase dès l'état embryonnaire, 3 jours avant la naissance des fotus, et l'on peut penser qu'un développement de la lipase pancréatique chez le Porcelet s'effectue au cours de la vie fotale.

\section{I 3. Variation du taux de lipase suivant la composition du régime.}

De nombreux travaux soulignent la présence d'une grande quantité de lipase dans le pancréas du Porc adulte ou même du Rat (DESNUELIE, I96I), alors que l'apport énergétique de la ration de ces animaux est à ce moment presque exclusivement glucidique. De même, BEN ABDELJLIL, et al. (I963) ne signalent aucune augmentation du taux de lipase du pancréas des rats recevant de très fortes quantités de lipides et sont amenés à conclure au caractère non adaptatif de la lipase en fonction de la teneur en lipides du régime.

\section{2. - Les enzymes protéolytiques}

I. 2 I. Les enzymes protéolytiques du tube digestif chez le jeune.

On les rencontre essentiellement à deux niveaux distincts du tube digestif. L'estomac séctète chez le jeune une pepsine (Hudman et al., I957). Au niveau de la lumière intestinale sont présentes de nombreuses protéases pancréatiques (fig. 2) la trypsine et la chymotrypsine sont bien connues, les autres ont été beaucoup moins étudiées.

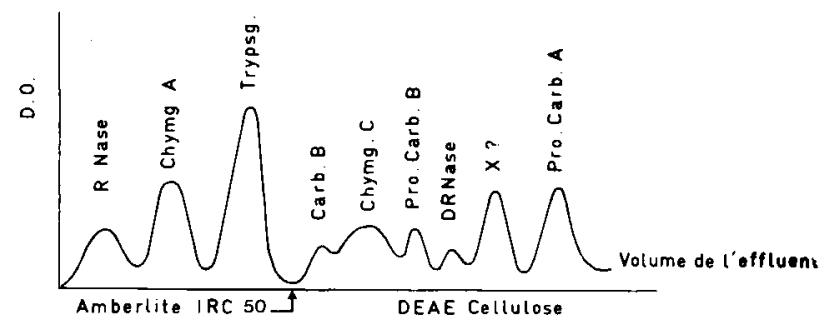

FIG. 2. - Différentes enzymes protéolytiques présentes dans le suc pancréatique de porcelet

Chez le Porcelet, grâce à l'utilisation de techniques spécifiques, nous avons mesuré l'activité de la trypsine et de la chymotrypsine du suc pancréatique obtenu à l'aide de fistules permanentes (RÉRA'T, I962). Nous avons observé une activité chymotrypsique importante à 30 jours, et une activité trypsique environ 4 à 5 fois plus faible dans le suc pancréatique (tabl. I) avec des variations entre animaux assez sensibles. Nos valeurs sont comparables à celles trouvées par BEN ABDELJLIL et DESNUELIE (I964) chez le Rat.

Enfin, les cellules muqueuses de l'intestin renferment des dipeptidases dont 1'identification chez le Porc (Josefsson et LindBerG) n'est qu'à ses débuts. Pour celles-ci on peut citer l'activité importante chez l'adulte de la $l$-glycine-l-leucine et de la $l$-glycine--l-valine hydrolases. 


\section{2 2. Développement de l'activité des enzymes protéolytiques du porcelet avec l'âge.}

En raison de la multiplicité des enzymes intervenant dans la digestion des protéines, de nombreux auteurs ont considéré l'activité protéolytique totale des organes ou des contenus intestinaux; les résultats proposés méritent donc encore de nombreuses précisions.

L'existence d'une activité pepsique a été prouvée par Hudmax at al. (I957) dans l'estomac du porcelet. Ces auteurs, bien qu'utilisant une technique de dosage assez peu spécifique, observent une augmentation de l'activité pepsique avec 1'âge des animaux, particulièrement nette à partir de 2 semaines d'âge. Ces résultats sont confirmés par BRAUDE et al. (I958) qui dosent une activité protéolytique dans le contenu stomacal lui-même, mettant en évidence la sécrétion de cette enzyme.

D'autres auteurs observent, avec l'âge, une variation du pH de l'estomac (WALKER, 1959; AUMAITRE et al., I964) surtout en relation avec le sevrage, et font l'hypothèse à la suite d'une diminution de la sécrétion de pepsine d'une digestion intestinale des protéines alimentaires après la suppression du lait. Les résultats de HARTMAN et al. (r96I) concernant l'augmentation de l'activité protéolytique totale du contenu intestinal avec l'âge appuient également cette hypothèse.

Au niveau pancréatique, Hudman et al. (I957) observent également une activité "trypsique " dès la naissance et une augmentation avec l'âge confirmée par les résultats de HarTman et al. (I96r) exprimés en termes d'activité protéolytique totale (tab1. 2). Les résultats disponibles sont cependant encore trop imprécis dans ce domaine pour conclure de façon définitive sur l'augmentation du pouvoir digestif de ces enzymes sécrétées dans l'intestin en fonction de 1'âge.

TABLEAU 2

Activité de la trypsine et de la chymotrypsine du tissu pancréatique des porcelets aux différents àges

(HudMaN et al., I957)

\begin{tabular}{|c|c|c|c|c|c|c|c|}
\hline Age (jours) $\ldots \ldots \ldots \ldots \ldots \ldots$ & 1 & 7 & $1 / 4$ & 21 & 28 & 35 & 42 \\
\hline Activité pepsique estomac - (1).. & 0,1 & 0,2 & 0,2 & 0,6 & 0,9 & 1,1 & 1,7 \\
\hline Activité "trypsique" pancréas - $(\stackrel{2}{)})$ & 1,0 & 0,75 & 1,1 & 0,5 & 0,5 & 1,0 & $\stackrel{2,}{2}$ \\
\hline
\end{tabular}

(1) Unités/gramme de tissu.

( $\left.{ }^{2}\right)$ Activité protéolytique totale.

Toutefois, on peut signaler des résultats récents obtenus sur le Rat allaité (CoRRING et AUMAITRE, I970) en accord avec les expériences globales de Kol,Dovsky (I966) ; ils concernent la mise en évidence de la présence de chymotrypsine en quantité importante dès la vie fotale et à la naissance, avec une augmentation constante (8 fois l'activité initiale) dans le pancréas jusqu'au sevrage. La trypsine évolue de façon identique, mais l'activité de nature différente, certes, est de 4 à 5 fois plus faible que celle de la chymotrypsine ; ces proportions confirment les valeurs relatives que nous avons observées dans le suc pancréatique du Porcelet allaité (tabl. I). 
I,es autres enzymes protéolytiques présentes dans le suc pancréatique n'ont pas encore été étudiées avec précision, aussi on ignore encore tout de l'activité des carboxypeptidases, des élastases etc. et de leurs variations.

I. 2 3. Adaptation des enzymes protéolytiques du porcelet suivant la composition du régime.

Dès I9I3, PAvi_ov a émis chez le Chien l'hypothèse de l'adaptation des sécrétions digestives et notamment des protéases à la nature du régime. Depuis, de nombreuses études effectuées sur le Rat ont montré la variation de certaines enzymes protéolytiques, suivant le taux de protéines de la ration. Ainsi, REBoud et al. (I962) ; BEN ABDELJ LIL, et al. (I963) observent une augmentation de la biosynthèse du chymotrypsinogène du pancréas du Rat lorsque son régime est riche en protéines.

Chez le Porcelet, nous avons observé de même des variations de Ioo $\mathbf{p}$. Ioo de l'activité spécifique du chymotrypsinogène du suc pancréatique (fig. 3) lorsque ]le taux protidique de la ration varie de 15 à 35 p. Ioo.

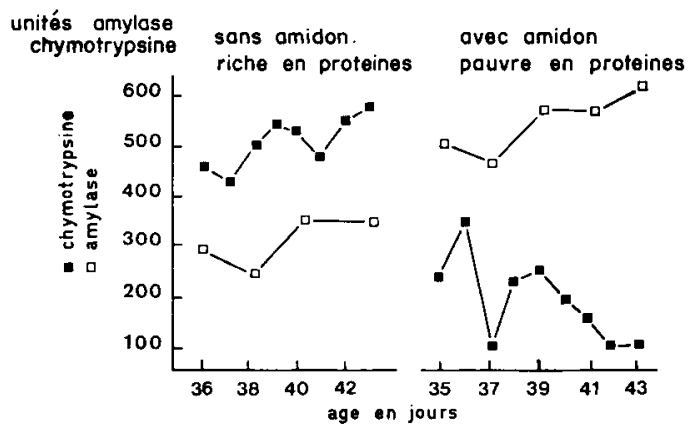

FIG. 3. - Variation de l'activité spécifique de l'amylase et de la chymotrypsine du suc pancréatique de porcelet suivant la composition du régime

(Aumaitre et Rérat, 1966)

TABLEAU 3

Sécrétion et composition du suc pancréatique après le repas, sur deux porcs porteurs d'une fistule pancréatique

et alimentés à partir de différentes sources protidiques à 45 jours d'age

(PEKAs et al., 1966)

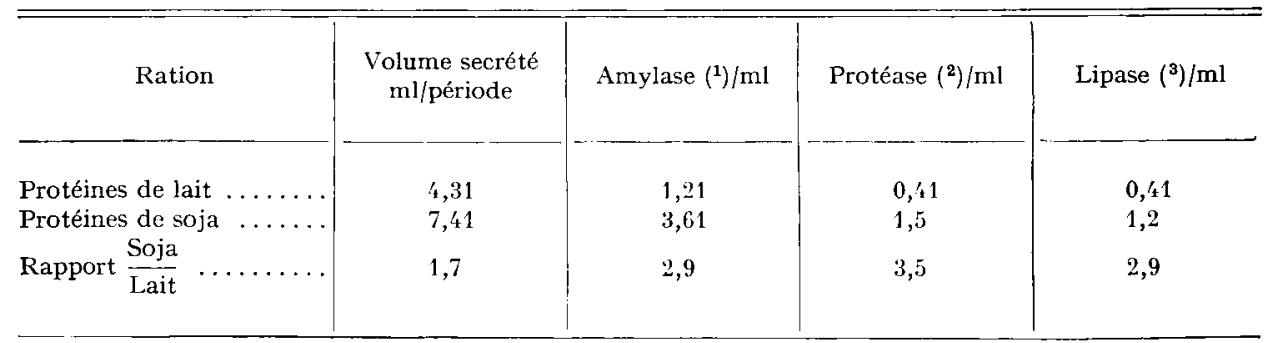

(1) $\mathrm{mg}$ de maltose $\times 10^{-3}$.

( $\left.{ }^{2}\right) \mathrm{mg}$ de trypsine (ou équivalent).

$\left({ }^{3}\right)$ Milliéquivalent de potasse $(\mathrm{KOH})$. 
De même PEkas et al. (Ig66) observent une variation de volume de suc pancréatique sécrété ainsi qu'une augmentation de l'activité protéolytique du suc pancréatique lorsque les animaux reçoivent une ration à base de tourteau de soja (tabl. 3) en remplacement de la poudre de lait écrémé.

L'introduction de protéines d'origine végétale dans la ration entraînerait une adaptation de la sécrétion pancréatique du jeune porcelet, notamment une augmentation de la quantité d'enzymes protéolytiques. De tels résultats ont été également signalés chez le Rat par SNOOK et MEYER (I964) qui ont observé une augmentation de la synthèse des enzymes protéolytiques du pancréas après substitution de la caséine par des protéines de blanc d'œuf. La chymotrypsine est plus sensible à cette variation qualitative ainsi qu'au taux de protéines du régime que la trypsine, et ceci confirme nos propres résultats.

\section{3. - Les enzymes glucolytiques}

L'alimentation du monogastrique et du Porc est riche en glucides dont la nature est très variable. En dehors des oses, chacun de ces sucres nécessite une ou plusieurs enzymes particulières pour son hydrolyse; ainsi, le nombre des enzymes glucolytiques dénombrées est-il important (BAIrEY et al., I956; DAHLQUIST, I960). De nombreux travaux leur ont été consacrés en raison de la nécessité économique d'introduire des glucides dans les rations de sevrage précoce et des problèmes physiologiques qui sont posés par leur utilisation (DoLLAR et al., I957).

\section{3 I. Multiplicité des enzymes glucolytiques chez le Porcelet.}

On peut classer schématiquement les enzymes glucolytiques présentes dans le tube digestif du porcelet (fig. 4) en deux grands groupes. Le premier type concerne les amylases dont le rôle essentiel est d'hydrolyser l'amidon. Le deuxième groupe est constitué par des glucosidases qui hydrolysent plus ou moins spécifiquement les différents diholosides de la ration (DAHLQUIST, I96I b). Les plus courantes, celles qui ont leur rôle important dans la digestion, chez le Porcelet sont la maltase, 1'isomaltase, 1'invertase, la lactase qui ont été étudiées par de nombreux auteurs.

LUMIERE INTESTINALE

CELLULES MUQUEUSES

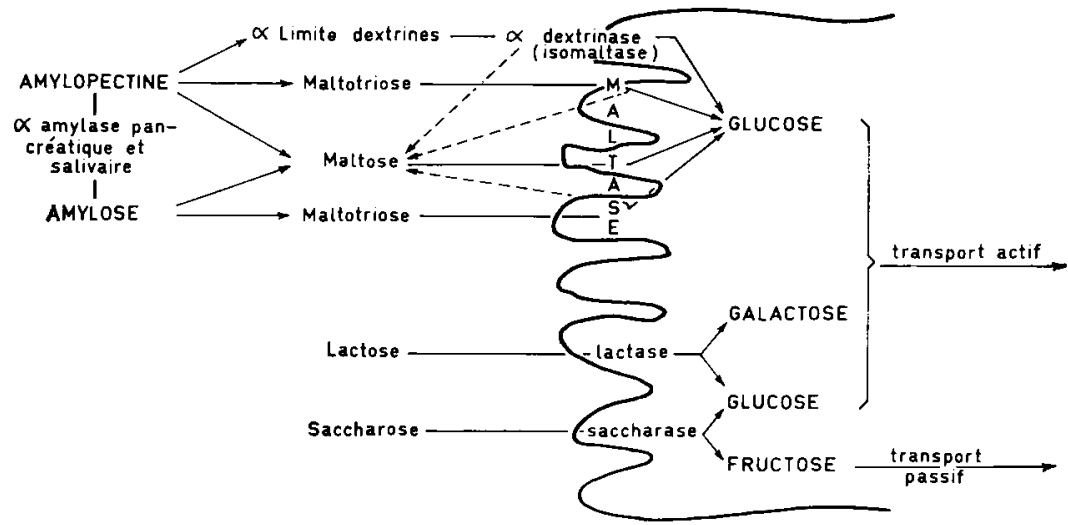

FIG. 4. - Les enzymes glucolytiques du tube digestif du porcelet: rôle et localisation 
L'origine et la localisation de ces enzymes est multiple, c'est ainsi que l'amylase est présente dans la salive des porcs, mais surtout dans le pancréas (Hudman et al., I957 ; une activité amylolytique est également dosée au niveau de la muqueuse intestinale. Enfin il n'est pas exclu que la flore intestinale puisse participer par ses propres synthèses à la dégradation des sucres.

Les maltases, lactase, invertase, sont présentes essentiellement au niveau des cellules de la muqueuse intestinale et du mucus (DAHLQUIST, I96I). Elles ont été signalées cependant dans le pancréas (BIERRY et 'TERroINE, I905) pour la maltase. Nous avons également caractérisé après Hudmax et al. (1957) une faible activité maltasique $d u$ suc pancréatique, ainsi qu'une faible activité lactasique dans le pancréas du Porc.

D'autres enzymes glucolytiques sont présentes (DAHLQUIST, I96I $a$ ), mais leur spécificité n'est pas absolue et leur rôle digestif encore mal précisé chez le Porcelet (cellobiase, trehalase etc).

I. 3. 2. Développement des enzymes glucolytiques avec l'âge du porcelet.

- Analyse.

KitTs et al. (I956), Hudman et al. (I957), Walker (I959) et Hartman et al. (I96r) observent une absence à peu près totale de l'amylase dans le tissu pancréatique du porcelet au moment de la naissance. L'activité de l'amylase intestinale, présente

TABLEAU 4

Activité des glucosidases du pancréas:

a) intestin grêle du porcelet nouveau-né

b) mucus de la première partie du jéjunum

(DAhLgUIST, I96I a)

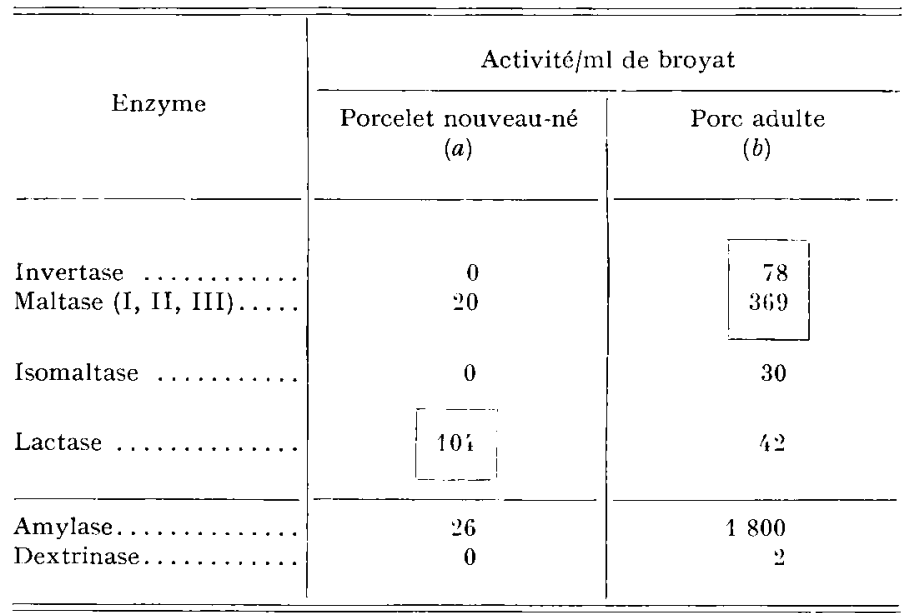

en faible quantité à la naissance, augmente (tabl. 4, fig. 5) jusqu'au stade adulte. Toutes ces études montrent d'autre part une augmentation du taux d'amylase pancréatique en fonction de l'âge, dès les premiers stades et jusqu'à 40 jours de la vie de l'animal. 
Cette observation concerne les valeurs absolues (unités totales par organe) et pourrait refléter le développement de l'organe. Elle se retrouve néanmoins lorsque les résultats sont exprimés par rapport au poids vif de l'animal (KITTs et al., I956) ou par rapport à l'unité de poids de tissu frais (HARTMAN et al., I96I). De même, nous avons mis en évidence (AUMAITRE et al., Ig64) une augmentation de l'activité amylolytique du suc pancréatique du porcelet avec l'âge, en même temps qu'une augmentation du volume sécrété, entre 4 et I I semaines. On peut ainsi conclure à une augmentation avec 1'âge de la biosynthèse de l'amylase dans le pancréas du porcelet et à une adaptation de l'animal à son régime d'adulte.

Ce phénomène s'observe chez d'autres animaux allaités comme le Rat (KoLDovsky et HAHN, I964). Un développement comparable de l'amylase a été trouvé chez d'autres animaux recevant un régime riche en amidon comme le Poussin (KULKA, I964) (fig. 5) dès le stade embryonnaire.
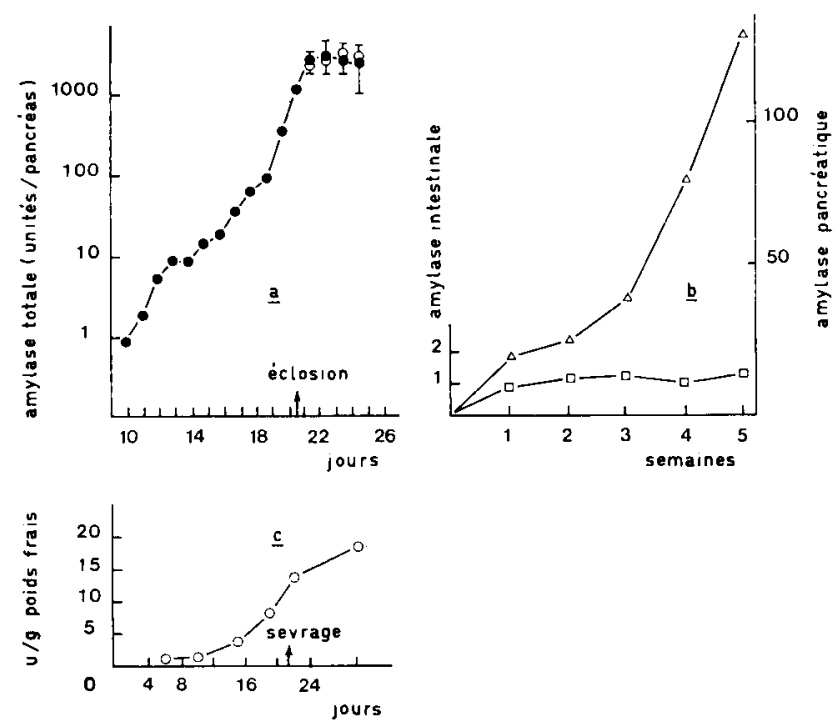

FIG. 5. - Activité de l'amylase pancréatique avec l'âge
a) Poulet
b) Porcelet
c) Rat

On peut donc s'interroger sur les mécanismes agissant sur la synthèse de l'amylase et son développement avec l'âge. Koldovsky et HaHN (I964) et YALovsky et al. (I969) concluent chez le Rat et chez le Poulet à l'effet spectaculaire de substances corticostéroïdes (corticostérone, hydrocortisone) dans le déclenchement ou la stimulation de cette synthèse. Ces données peuvent être retenues comme hypothèse pour expliquer le contrôle de la synthèse de l'amylase chez le Porcelet à partir de la naissance, alors que l'animal reçoit un régime lacté exclusif.

- Maltase, lactase, invertase.

C'est surtout au niveau intestinal que les enzymes hydrolysant les glucosides ont été plus particulièrement étudiées (DAHLQUIST, I960). La lactase présente généralement une activité élevée à la naissance (BAILEY et al., I956; WAL,KER, I959; 
Hartman et al., I96I; Dahlquist, I961 a). Son taux reste constant ou diminue légèrement avec l'âge. Ce phénomène est caractéristique de beaucoup d'animaux allaités, le Rat, la Souris et le I apin (Kor,Dovskr, I966). Par contre, on observe une augmentation de l'activité des maltases lorsque l'on considère la somme de l'activité des trois maltases identifiées (fig. 6 et tabl. 4) ainsi qu'une augmentation de l'activité de 1'invertase à partir de la première semaine.

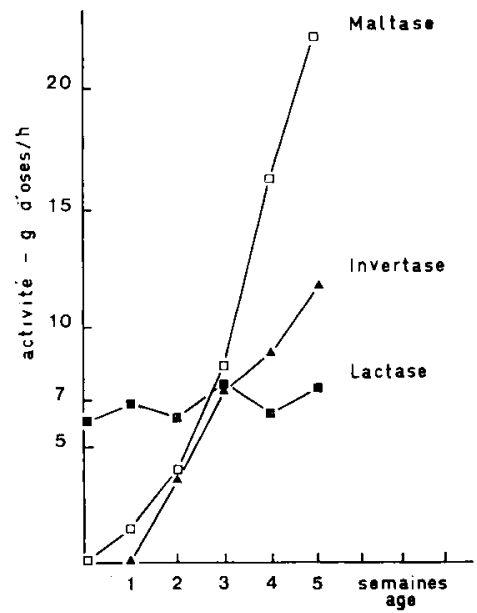

FIG 6. -- V'ariation avec l'âge de l'activité des glucosidases dans l'intestin du Porcelet

On peut souligner une véritable adaptation avec l'âge des principales enzymes glucolytiques de l'intestin au fur et à mesure que le Porcelet vieillit et que son régime subit des variations dans sa composition et notamment une variation qualitative et quantitative dans l'apport glucidique.

\section{3. 3. Adaptation suivant la composition du régime.}

L'augmentation de l'activité des principales enzymes chez les animaux allaités peut s'expliquer à la fois avec l'âge et la composition du régime, car les jeunes consomment progressivement, en plus du lait, un aliment complémentaire riche en glucides (amidon, saccharose...).

Or 1'adaptation des enzymes pancréatiques et en particulier de 1'amylase à la composition du régime a été abondamment prouvée. Ainsi les travaux de REBoud et al. (I962), Ben Abdeijlil, et Desnuelile (I964) ; Howard et Yudkin (I963) ont montré un tel phénomène dans les tissus pancréatiques du rat adulte.

Nous retrouvons un résultat comparable chez le Porcelet porteur d'une fistule pancréatique (AUMAITRE et RÉRAT, Ig66; fig. 7) lorsqu'on change la composition du régime du porcelet vers un mois d'âge. Cinq jours après la distribution d'un aliment riche en amidon, le taux d'amylase du suc pancréatique (exprimé en unités par millilitre de suc) est multiplié par 2 à 2,5 en accord avec les résultats observés sur le Rat (BEN ABDELJLIr, et al., I963). Le même phénomène s'observe lorsque l'on compare le taux d'amylase de deux porcelets recevant soit un régime sans amidon, soit un régime très riche en amidon (fig. 3 ). 
Cette adaptation de 1'amylase semble se faire aux dépens des enzymes protéolytiques comme l'ont montré les auteurs précédents et en particulier aux dépens de la chymotrypsine dont le taux est plus faible lorsque le régime est riche en amidon. Nos résultats montrent de plus que l'adaptation reste indépendante de la lipase dont le taux reste constant, quel que soit le taux de l'amylase (fig. 7).

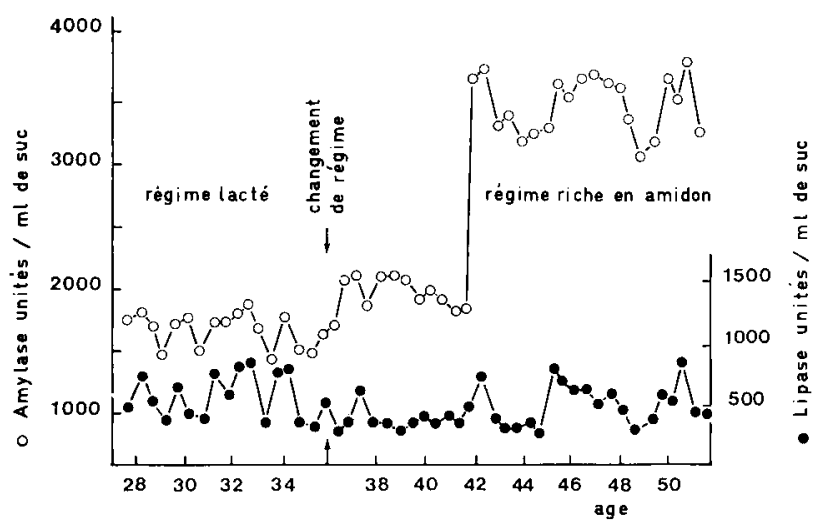

Fig. 7. - Activité de deux enzymes pancréatiques après un changement de composition de l'aliment (Aumaitre et RÉrat, ig66)

En conclusion, il semble donc que le Porcelet soit bien pourvu dès la naissance en certaines enzymes nécessaires au fonctionnement de son tube digestif, la lipase et la lactase par exemple, et qu'il se produit une adaptation avec l'âge et la variation de la composition de sa ration. De nouvelles enzymes sont donc synthétisées dans le tube digestif : c'est le cas de l'amylase pancréatique et de la maltase intestinale. Cependant, leur apparition n'est pas instantanée dès la naissance, mais progressive suivant l'âge et les animaux, et ce phénomène se rencontre chez presque tous les jeunes mammifères allaités.

\section{II. - IMPORTANCE DES ENZYMES DANS LA DIGESTION CHEZ LE MONOGASTRIQUE}

\section{I. - Rôle des enzymes dans la digestion chez le Porcelet}

\section{I. I. Digestion enzymatique des lipides.}

L'action de la lipase pancréatique conduit à une libération d'acides gras au niveau de la lumière intestinale à partir des graisses émulsionnées. On admet classiquement que les triglycérides sont hydrolysés en di-, monoglycérides et en acides gras (FRAZER, I943) avant d'être absorbés au niveau des villosités.

L'activité ou vitesse d'hydrolyse de la lipase mesurée in vitro semble varier suivant l'origine des lipides et en même temps avec leur état de conservation (AUMAITRE et RÉRAT, I968). Le saindoux, la graisse du lait de Truie, les huiles d'olive et de maïs sont hydrolysées à une vitesse élevée, le suif présente une vitesse légèrement plus faible (fig. 8), alors que le coprah est hydrolysé à une vitesse très rapide. 
Chez le Porcelet, l'ensemble des résultats montre que l'activité lipasique est très élevée et suffisante dès la naissance pour hydrolyser tous les lipides alimentaires qu'il reçoit à différents âges de sa vie.

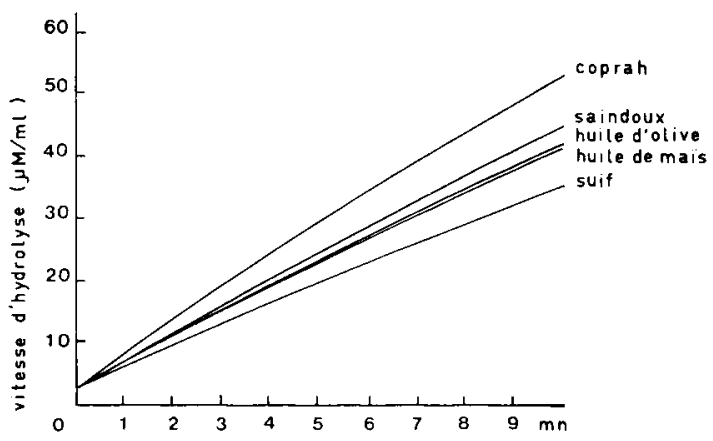

FIG. 8. - Vitesse d'hydrolyse de differentes graisses par une même quantité de suc pancréatique de porcelet

(Aumaitre et RÉrat, I968)

\section{I. 2. Digestion enzymatique des protéines chez le Porcelet.}

Les processus impliqués dans la digestion des protéines chez le nourrisson, puis chez l'animal sevré sont assez complexes et encore mal connus. Ils se situent d'abord au niveau stomacal après l'action de l'acide chlorhydrique sur les structures tertiaire et secondaire des protéines. L'action de la pepsine se situerait au niveau de la structure primaire des protéines, sans spécificité.

Au niveau de la lumière intestinale, interviennent simultanément, après activation, la trypsine et la chymotrypsine très spécifiques de la rupture de la chaîne peptidique au niveau de certains acides aminés (fig. 9). Le rôle des autres protéases pancréatiques est encore très mal connu.

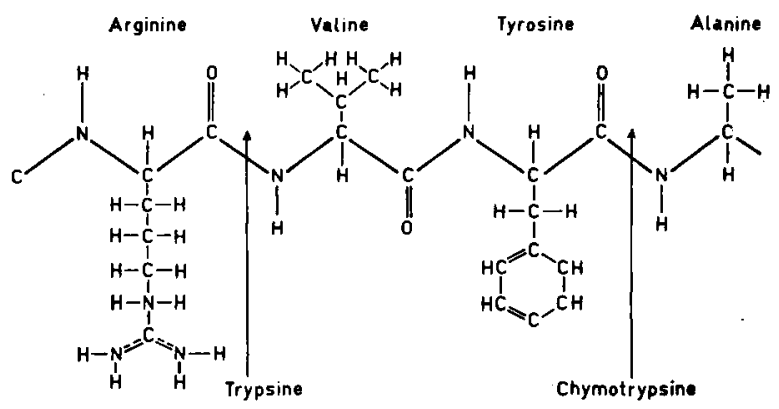

F1G. 9. - Spécificité d'action de la trypsine et de la chymotrypsine (Neurath, I964)

Les peptidases des cellules muqueuses (dipeptidases ou tripeptidases) dégraderaient ensuite les peptides simples pour libérer les acides aminés (LINDBERG, I966), mais leur rôle est encore très mal précisé.

Ainsi faute d'une connaissance du rôle de certaines enzymes protéolitiques, les études relatives à leur activité chez le Porcelet ont été très limitées. Souvent, on se borne à exprimer une activité protéolytique totale et à considérer le rôle digestif de la trypsine et de la chymotrypsine comme fondamental. 
Cependant, on sait qu'au cours de l'allaitement, la digestion des protéines du lait est mixte (stomacale et intestinale), elle devient ensuite du type intestinal en raison de la faiblesse à la fois de la sécrétion de pepsine (Hudman et al., 1957) et de l'acide chlorhydrique et surtout du changement de la nature des protéines alimentaires (protéines végétales). On observe ainsi une augmentation de l'activité protéolytique dans 1'intestin avec 1'âge (BRAUDE et al., I958).

\section{I. 3. Digestion des glucides chez le Porcelet.}

Le sevrage s'accompagne chez le Porcelet d'un changement dans la nature des glucides de son régime. Le régime lacté renferme du lactose dont l'hydrolyse en oses est relativement simple. Le régime concentré, comme la nourriture de l'adulte, est riche en amidon dont la digestion nécessite une série d'étapes relativement complexes (fig. 4 et Io).

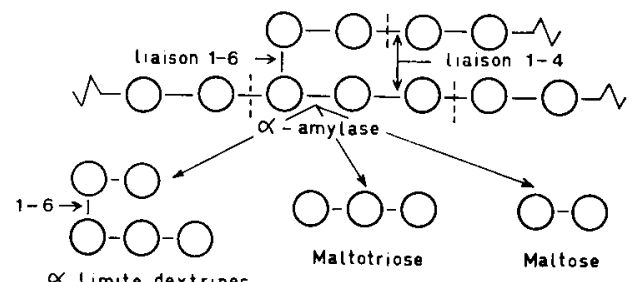

FIG. Io. - Schéma de l'hydrolyse enzymatique de l'amidon dans l'intestin du Porcelet
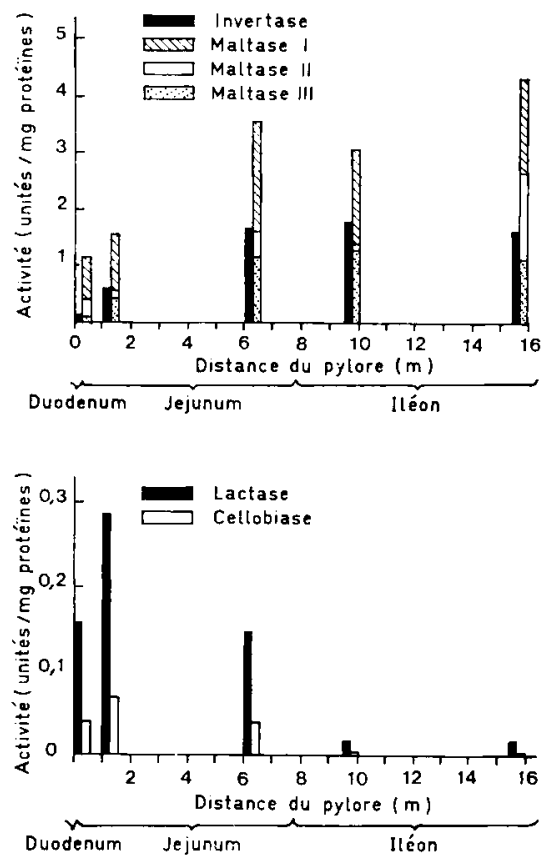

FIG. I I. - Activités enzymatiques de l'intestin du Porc: importance et localisation de l'invertase, des maltases $I$, II et III, de la lactase et de la cellobiase 
L'hydrolyse complète de l'amidon en produits faciles à absorber (glucose) nécessite au préalable l'action d'une amylase qui le transforme en majorité en maltose, mais aussi en maltotriose, en produits linéaires comportant un nombre d'unités glucose variable, mais également en produits " branchés " comme les $\alpha$-limite dextrines.

L'hydrolyse des diholosides présents dans la ration (ou formés au cours de la digestion de l'amidon) nécessite 1'action des enzymes spécifiques de la partie muqueuse de l'intestin. Leur localisation, variable suivant les enzymes conduit à une digestion des différents diholosides à des niveaux d'hydrolyse assez bien délimités (DAHLQUisT, I96I $a$ et $b$; Bouman et al., I969) mais on n'en connaît pas exactement la signification physiologique (fig. II). L'hydrolyse du maltotriose est également réalisée par la maltase, celle des $\alpha$-limite dextrines par l' $\alpha-\mathrm{r}-6$ glucosidase de l'intestin (LARNER et MCNICKI,E, I955; DALHQUIST, I963).

La digestion des glucides est donc tributaire de la présence dans le tube digestif d'une série d'enzymes dont l'action successive conduit à la libération de molécules facilement assimilables (glucose, galactose, fructose).

\section{2. - Conséquences physio-pathologiques}

d'un manque d'enzymes chez le nourrisson

Seules deux catégories d'enzymes sont à certains stades de la vie du jeune porcelet en quantité insuffisante pour digérer les aliments qui leur sont offerts soit par voie naturelle (lait) soit par un aliment concentré : ce sont les enzymes protéolytiques et les enzymes glucolytiques. Le manque d'enzymes protéolytiques est surtout signalé chez le nourrisson humain et accessoirement chez le Porc, il se traduit par une impossibilité de digérer les protéines des céréales et semble en partie responsable de la maladie cœliaque (LÉVESQUE, I955). Le manque d'enzymes glucolytiques est beaucoup plus

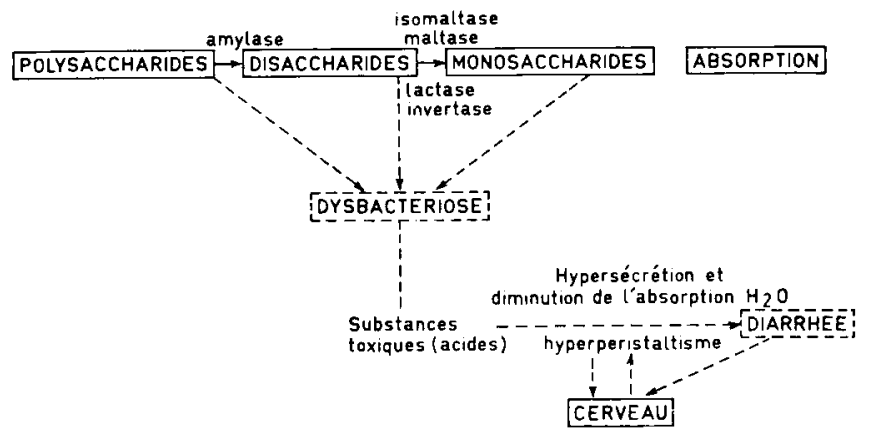

FIG. I2. - La diarrhée du nourrisson au moment du sevrage

(Weijers et VAN DE Kamer, I965)

fréquent et mieux étudié. Il conduit à des diarrhées fermentaires de l'animal allaité (fig. 12) dont la gravité est bien connue (Weijers et VAN DE KAMER, ig65). Les fermentations protéolytiques conduisent à des désordres digestifs de gravité comparable. Cependant, il a été démontré (Bouman et al., 1969) que le manque de glucosidases n'est pas seul responsable de la diarrhée blanche du porcelet que l'on constate dès 8 jours d'âge. 
Par contre, la gastroentérite (tabl. 5) s'accompagne d'une diminution considérable de l'activité des enzymes pancréatiques présentes dans la lumière intestinale, mais on ne sait pas si le manque d'enzyme est la cause ou la conséquence de ce trouble digestif (JuHAsz et al., I967).

TABLEAU 5

Activité des enzymes pancréatiques (amylase et lipase) chez les porcs normaux ou atteinis de gastroentérite

(JuHAsz et al., I967)

\begin{tabular}{l|c|c|c|c}
\hline \hline Examens post mortem & $n\left({ }^{1}\right)$ & $\begin{array}{c}\text { Amylase } \\
\text { unités/g } \\
\text { de pancréas }\end{array}$ & $n\left({ }^{1}\right)$ & $\begin{array}{c}\text { Lipase } \\
\text { unités/g } \\
\text { de pancréas }\end{array}$ \\
\hline Animaux normaux ...... & 68 & 265.400 & 40 & 11.040 \\
Début de diarrhée ...... & 80 & 16.500 & 57 & 3.780 \\
Gastro-entérite infectieuse & 39 & 14.500 & 31 & 2.650 \\
\hline Signification : & & $\mathrm{P}<0,001$ & & $\mathrm{P}<0,001$ \\
Normaux malades .... & & & & \\
\hline
\end{tabular}

(1) Nombre d'animaux.

III. - SIGNIFICA'TION NUTRITIONNELLE

DE L'ADAPTATION DES ENZYMES DIGESTIVES DU JEUNE :

\section{I. - Tolérance des aliments par le jeune}

De nombreux essais visant à la détermination des éléments pouvant être utilisés pour le sevrage précoce du porcelet ont été tentés. Différents glucides dérivés de l'amidon ont été testés au préalable chez le Porcelet (Dollar et al., I957 ; CunNINGHAM et BRISSON, I.957 ; BRAUDE et al., I.958.

Ainsi, on a pu mettre en évidence une tolérance parfaite du porcelet pour le glucose et le lactose dès la naissance, une intolérance à peu près complète pour le maltose et le saccharose et une intolérance totale à 1'amidon cuit ou cru. Avec 1'âge, on peut conclure à une bonne tolérance au saccharose entre 9 et II jours, puis une tolérance a11 maltose entre 15 et 22 jours.

La tolérance aux dextrines "cuites" apparaît entre 8 et $\mathrm{r} 2$ jours (BRAUDE et al., I958). En ce qui concerne l'amidon les résultats sont encore imprécis, voire contradictoires ; ainsi la tolérance apparaît dès I5 jours pour l'amidon de pommes de terre cuites, vers 23 jours pour l'amidon de blé cru selon BRAUdE et al. (I958) et à 42 jours seulement selon Cunningham (I959) pour l'amidon de maïs.

Ainsi, il apparaît, parallèlement au développement des enzymes glucolytiques, avec l'âge du porcelet une augmentation de la tolérance aux sources de glucides les plus complexes (amidon cru), et l'ensemble de ces transformations irréversbles préparent l'animal à la digestion de sa ration d'adulte. 


\section{2. - Evolution de la digestibilité des éléments de la ration avec l'âge}

L'utilisation digestive globale de la ration varie avec l'âge du porcelet. Cependant, on a pu noter une très faible variation (AUmaITRE, 1965) de l'utilisation digestive des lipides qui est toujours très élevée. La digestibilité apparente des protéines et des glucides varie dans des limites plus larges suivant leur nature et l'âge de l'animal.

\section{2. I. Effet de la nature des protéines sur leur digestibilité.}

Les protéines du lait de la mère sont bien utilisées par le Porcelet dès sa naissance. Ainsi nous avons pu observer un coefficient de digestibilité apparente de $9^{8}$ p. Ioo (Aumaitre, 1965) des protéines du lait de Truie.

Chez l'animal sevré précocement Hays et al. (I959), Combs et al. (I963) et PEKas et al. (1964) signalent une augmentation de la digestibilité des protéines entre 3 et 8 semaines pour la farine de poisson et le tourteau de soja (tabl. 6).

TABLEAU 6

Digestibilité apparente des protéines de sources différentes par le porcelet sevré précocement

(ComBs et al., 1963)

\begin{tabular}{c|c|c|c}
\hline Régine & $\begin{array}{c}\text { Poudre de } \\
\text { lait écrémé }\end{array}$ & $\begin{array}{c}\text { Tourteau de } \\
\text { soja }\end{array}$ & $\begin{array}{c}\text { Farine de } \\
\text { poisson }\end{array}$ \\
\hline Digestibilité p. $100:$ & $-\ldots \ldots \ldots$ & & \\
3-4 semaines $\ldots \ldots \ldots \ldots$ & 84 & 80 & 79 \\
$5-6$ semaines $\ldots \ldots \ldots \ldots$ & 85 & 81,5 & 79 \\
$7-8$ semaines $\ldots \ldots \ldots \ldots$ & 89 & 88 & 87 \\
\hline
\end{tabular}

De même PeKas et al. (Ig60 et I964) soulignent l'influence fondamentale de la sécrétion pancréatique dans la digestion des protéines : ils observent en effet une baisse de la digestibilité des protéines lorsque la sécrétion pancréatique est dérivée ou lorsqu'on ligature le canal pour empêcher la sécrétion dans l'intestin.

Ainsi, dans tous les cas, on observe un parallélisme entre l'utilisation digestive des protéines et l'activité des sécrétions protéolytiques d'origine pancréatique dans la lumière intestinale. Le phénomène le plus important reste l'augmentation parallèle avec l'âge de l'activité de ces enzymes, la chymotrypsine en particulier, et de la digestibilité des protéines d'origine végétale contenues dans la ration.

\section{2. 2. Effet de la nature des glucides sur leur digestibilité.}

Les tests de tolérance sont insuffisants pour expliquer les phénomènes quantitatifs concernant l'utilisation de divers glucides dans la ration du porcelet. Les résultats obtenus par BECKER et al. (1957) montrent que l'animal utilise remarquablement bien le lactose à des doses élevées. De même, les travaux de Cunningram (I959) nous précisent les différences observées dans la digestibilité de différents glucides (tabl. 7). 
TABLEAU 7

Digestibilité apparente des glucides (1) par le jeune porcelet

(Cunningham, 1959)

\begin{tabular}{c|c|c|c|c}
\hline \hline Age (jours) & Glucose & Maltose & $\begin{array}{c}\text { Amidon } \\
\text { soluble }\end{array}$ & $\begin{array}{c}\text { Amidon } \\
\text { cru }\end{array}$ \\
\hline & & & 88 & \\
\cline { 2 - 4 } Naissance & 87 & 84 & 64 & 25 \\
15 & 97 & 89 & 78 & 32 \\
25 & 98 & 48 \\
\hline
\end{tabular}

(1) Distribués par tubage stomacal.

On constate que le Porcelet utilise une quantité de glucides d'autant plus grande que le poids moléculaire est plus faible. Le glucose et le lactose sont ainsi tolérés à tous les âges et très bien utilisés. Pour l'amidon, le maltose et le saccharose, on observe une augmentation de la digestibilité avec l'âge de l'animal, qui confirme à la fois les observations des différents auteurs sur le développement des sécrétions glucolytiques et l'augmentation de la tolérance de l'animal à ces glucides.

Enfin, il convient de souligner un effet très important de la nature des glucides sur la digestibilité globale de la ration. Le lactose améliore l'utilisation digestive des autres éléments de la ration (SEWELL et WEST, I965) alors que certaines dextrines solubles la diminuent significativement (SEWELL et MAXWELL, I966).

\section{3. - Limites de nos conceptions sur le rôle des enzymes dans les phénomènes de digestion chez le Porcelet}

De nombreux essais réalisés à la fois au laboratoire et dans les conditions pratiques ont été tentés en vue de remplacer le lait de la mère par un lait synthétique de composition appropriée et renfermant des composants végétaux peu coûteux.

Compte tenu de l'impossibilité ou de la difficulté des animaux à digérer certains glucides ou certaines protéines, on a envisagé deux types de palliatifs, soit la supplémentation enzymatique des aliments, soit leur traitement technologique.

\section{3. I. Supplémentation des aliments en enzymes.}

Dès I955, LEWIS et al. ont préconisé la supplémentation des rations pour porcelets sevrés précocement. Les premières recommandations concernaient l'efficacité d'une supplémentation en pepsine de régimes à base de protéines de soja pour porcelets sevrés à une semaine (LEWIS et al., I955). Cependant, l'effet bénéfique d'une telle supplémentation n'a pas été retrouvé par CALDER et al., (I959), Combs et al., (I960), MANER et al. (I959) qui n'ont pas fourni d'explication au phénomène.

La supplémentation des régimes en enzymes amylolytiques a été beaucoup plus étudiée. Les résultats positifs de LEWIS et al. (I955) ont été confirmés par GOMEZ et al. (I965), (Burnetrir et NeIL (I964) sur le Porcelet et par JENSEN et al. (I957), Colombus et Gober, (I958) sur le Poulet. Par contre, d'autres auteurs, Combs et al., 
(I960), Calder et al. (I959), Aumaitre et al. (1964) (tabl. 8) n'ont pas retrouvé d'effet positif des enzymes amylolytiques sur la croissance des animaux, la digestibilité de la ration ou même l'activité amylolytique du contenu intestinal.

\section{TABLEAU 8}

Effet d'une supplémentation en enzymes (amylases)
de la ration sur les performances des porcelets

(AUMAitre et al., I964-I966)

\begin{tabular}{|c|c|c|c|c|c|}
\hline \multirow[b]{2}{*}{ Enzyme d'origine } & \multirow{2}{*}{$\begin{array}{c}\mathrm{pH} \\
\text { optimum }\end{array}$} & \multirow{2}{*}{$\begin{array}{l}\text { Traitement } \\
(\mathrm{T}=\text { témoin })\end{array}$} & \multicolumn{2}{|c|}{ Performances $\left({ }^{1}\right)$} & \multirow{2}{*}{$\begin{array}{c}\text { Indice de } \\
\text { consommation }\end{array}$} \\
\hline & & & $\begin{array}{c}\text { Gain } \\
\text { journalier }\end{array}$ & $\begin{array}{l}\text { Aliment } \\
\text { ingéré }\end{array}$ & \\
\hline Amylase & & & & & \\
\hline$\underset{(\alpha 1,4)}{\text { Aspergillus niger }} \ldots \ldots \ldots \ldots \ldots$ & 4,0 & $\begin{array}{c}\mathrm{T} \\
15 \mathrm{mg} / \mathrm{kg}\end{array}$ & $\begin{array}{l}424 \\
405\end{array}$ & $\begin{array}{l}661 \\
720\end{array}$ & $\begin{array}{l}1,56 \\
1,78\end{array}$ \\
\hline $\begin{array}{l}\text { Bacillus subtilis } \ldots \ldots \ldots \ldots \ldots \\
(\alpha 1,4)\end{array}$ & $5-6,5$ & $\begin{array}{c}\mathrm{T} \\
25 \mathrm{mg} / \mathrm{kg} \\
50 \mathrm{mg} / \mathrm{kg}\end{array}$ & $\begin{array}{l}307 \\
300 \\
320\end{array}$ & $\begin{array}{l}598 \\
580 \\
572\end{array}$ & $\begin{array}{l}1,92 \\
1,89 \\
1,98\end{array}$ \\
\hline $\begin{array}{l}\text { Glucamylase } \\
\qquad \begin{array}{l}(\alpha 1,4-\alpha 1,6) \\
\text { Rhizopus Delemar . . . . . . . . }\end{array}\end{array}$ & 5,0 & $\begin{array}{c}\mathrm{T} \\
25 \mathrm{mg} / \mathrm{kg} \\
50 \mathrm{mg} / \mathrm{kg}\end{array}$ & $\begin{array}{l}328 \\
331 \\
327\end{array}$ & $\begin{array}{l}619 \\
611 \\
617\end{array}$ & $\begin{array}{l}1,93 \\
1,86 \\
1,89\end{array}$ \\
\hline
\end{tabular}

(1) g/jour, moyenne de 20 porcelets.

Enfin, pour éliminer l'influence éventuelle de la source d'amylase utilisée, nous avons entrepris la comparaison de l'effet de trois enzymes d'origine et de propriétés différentes (tab1. 8).

Les résultats obtenus sur les performances de croissance des animaux confirment l'inefficacité de la supplémentation en amylase aux doses étudiées.

\section{3. 2. Origine de l'amidon, ses traitements technologiques.}

Il est bien connu que l'amidon présente une plus grande facilité d'attaque par les enzymes amylolytiques suivant sa nature et son origine botanique (RADLEY, I953; Guilbot, I968). De même, il a été démontré in vitro (AuMAITRE et RǴRAT, Ig66) que la vitesse de son hydrolyse par le suc pancréatique de porcelet varie suivant son origine (fig. I3). L'amidon des céréales est plus rapidement et plus quantitativement hydrolysé que l'amidon de manioc ou que l'amidon de pomme de terre.

La comparaison expérimentale de l'effet de l'origine de l'amidon sur les performances du porcelet récemment sevré (tabl. 9) nous permet de constater, par contre, qu'il n'existe aucune différence entre la vitesse de croissance et l'efficacité alimentaire de régimes à base d'amidon de mais, de manioc ou de pomme de terre, lorsqu'ils sont introduits au même taux dans un régime qui subit un passage à la presse pour sa granulation. 


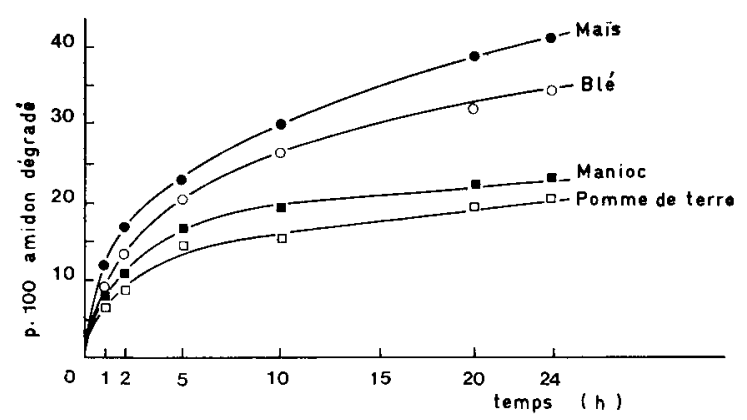

FIG. I3. - Vitesse d'amylolyse après empesage de divers amidons par le suc pancréatique de Porcelet

\section{TABLEAU 9}

Effet de l'origine botanique de l'amidon sur les performances des porcelets sevrés précocement (1)

\begin{tabular}{|c|c|c|c|c|c|}
\hline \multirow{2}{*}{ Sources d'amidon } & \multirow{2}{*}{$\begin{array}{c}\text { Dimension du } \\
\text { grain }(\mu) \\
\text { d'amidon }\end{array}$} & \multirow{2}{*}{$\begin{array}{l}\text { Vitesse d'hydrolyse } \\
\text { relative }\left({ }^{2}\right)\end{array}$} & \multicolumn{2}{|c|}{$\begin{array}{l}\text { Performances } \\
\qquad(\mathrm{g} / \mathrm{j} .)\end{array}$} & \multirow{2}{*}{$\begin{array}{c}\text { Indice de } \\
\text { consommation }\end{array}$} \\
\hline & & & $\begin{array}{l}\text { Gain de } \\
\text { poids }\end{array}$ & $\begin{array}{l}\text { Aliment } \\
\text { ingéré }\end{array}$ & \\
\hline Maïs $\ldots \ldots \ldots \ldots \ldots$ & $14(10-25)$ & 100 & 397 & 620 & 1,58 \\
\hline Manioc ............ & 20 & 71 & 383 & 614 & 1,59 \\
\hline Pomme de terre ..... & $40(10-100)$ & 58 & 397 & 618 & 1,56 \\
\hline
\end{tabular}

(1) 5 semaines au sevrage; 55 p. 100 d'amidon dans la ration.

(2) In vitro, par le suc pancréatique (après 5 heures d'hydrolyse).

\section{TABLEAU IO}

Effet des traitements technologiques de l'amidon (hydrolyse) sur les performances moyennes des porcelets au sevrage

\begin{tabular}{|c|c|c|c|}
\hline & $\begin{array}{l}\text { Gain de } \\
\text { poids (1) }\end{array}$ & $\begin{array}{l}\text { Aliment } \\
\text { ingéré }(\mathbf{1})\end{array}$ & $\begin{array}{c}\text { Indice de } \\
\text { consommation }\end{array}$ \\
\hline Amidon de maïs & $45^{\prime 4}$ & 721 & 1,57 \\
\hline Amidon prégélatinisé .... & 454 & $73\}_{t}^{\prime}$ & 1,61 \\
\hline Dextrine insoluble $\ldots . \ldots$ & 461 & 768 & 1,67 \\
\hline Dextrine soluble . . . . . . . & $319 * *$ & $591 * *$ & $1,84 * *$ \\
\hline Maltodextrine ........ & $402 *$ & 689 & 1,71 \\
\hline Cérélose ............ & 454 & 780 & 1,70 \\
\hline
\end{tabular}

(1) g/jour entre 35 et 63 jours ; 10 porcelets/traitement.

*, ** Différences significatives au seuil 5 p. 100 ou 1 p. 100. 
D'autre part, certains traitements technologiques, le gonflement, la dextrinisation, facilitent 1'attaque du grain d'amidon par les enzymes (GuIL, 130', I968). Ces traitements, qui améliorent la tolérance du porcelet aux dextrines, ne semblent pas de même améliorer les performances de croissance des animaux récemment sevrés (tabl. Io).

La dextrinisation trop poussée semble même entraîner en effet une diminution de la digestibilité (tabl. I I), non seulement du glucide lui-même, mais également des autres éléments de la ration (SEWE,L, et MAXWELL, I966). Ces résultats méritent cependant d'être confirmés sur un éventail beaucoup plus large d'amidons traités, et font l'objet de travaux en cours.

TABIEAU I I

Coefficient de digestibilité des rations contenant différentes sources de glucides et d'amidon cru ou traité

(SEWEL et MAXWELl, I966)

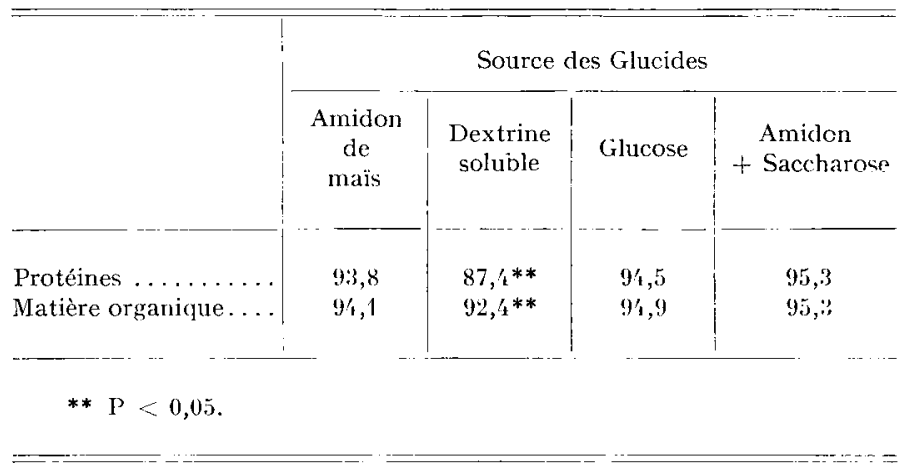

\section{4. - Conséquences pour le serrage des animaux}

I,es phénomènes les plus importants observés au cours des différentes études concernent l'adaptation de l'animal, avec l'âge, au régime de sevrage dont la composition est voisine de celle de l'adulte.

On constate en effet avec l'âge une adaptation de l'animal et de son tube digestif, en particulier par ses sécrétions, à une nouvelle source de protéines et à une nouvelle source de glucides.

Ainsi, le développement des enzymes protéolytiques du pancréas et des enzymes amylolytiques et maltasiques permet une substitution progressive de l'alimentation lactée exclusive et son remplacement par un aliment moins cotiteux, à base de tourteau de soja et de céréales par exemple.

La séparation du porcelet et de sa mère devient naturellement possible lorsque l'animal y est préparé, son sevrage pourra s'opérer dans les meilleures conditions. Compte tenu des données précédentes, on peut situer, suivant les animaux, l'âge optimal au sevrage entre 3 et 5 semaines. 


\section{CONCLUSIONS}

Les apports expérimentaux concernant l'existence, l'activité et le développement des enzymes digestives du porcelet ont permis au cours des quinze dernières années, de préciser l'évolution, et même l'adaptation avec 1'âge, de la physiologie digestive du porcelet.

Les études nutritionnelles et physiologiques ont également permis de souligner le rôle particulier des enzymes dans la digestion des différents éléments de la ration du jeune porcelet allaité, puis au cours de son sevrage. D'autre part, les données récentes concernant à la fois la toléranre des animaux à différents aliments, ainsi que leur utilisation digestive en fonction de divers traitements, nous permettent actuellement de raisonner le sevrage sur des bases physiologiques respectant le fonctionnement normal du tube digestif en précisant la nature des aliments à utiliser.

On peut enfin penser que le sevrage sera réussi à partir de rations concentrées distribuées à sec, non pas en incorporant à la ration de l'animal des aliments prédigérés ou supplémentés en enzymes déficients, mais en préparant 1'animal, en faisant notamment adapter le jeune à son nouvel aliment.

Cette adaptation des possibilités digestives de 1'animal nous paraît progressive dans le temps et il convient de respecter ce phénomène naturel, de le faciliter pour proposer une technique de sevrage du jeune porcelet, basée sur la connaissance de la physiologie du tube digestif.

$$
\text { Reçu pour publication en juin } 1971 .
$$

\section{SUMMARY}

ENZYME DEVELOPMENT IN THE DIGESTIVE TRACT

OF THE SUCKLING PIG : NUTRITIONAL SIGNIFICANCE AND IMPORTANCE FOR WEANING (1)

This work is a review of the personnal and numerous and recent experiments carried out on the digestive physiology of the suckling pig around weaning time. The attention of different workers was drawn around 1955 by Lewis $e t$ al. who concluded in a lack in the enzymatic development of the digestive glands during the suckling period.

The first chapter gives us a general point of view about the existence of different kinds of enzymes.

The lipase content of the pancreas is very high at birth and no marked increase is shown during the suckling period. The proteolytic content of the pancreas varies according to the age and to the level of crude protein of the diet. The different carbohydrases present a typical variation during the early period : the intestinal lactase activity is at the higher level at birth and seems to be constant with the age. On the contrary, maltase activity of the small intestine and pancreatic amylase increase markedly according to the age and to a variation of the food composition of the pig.

In a second chapter, the importance of the digestive enzymes on the hydrolysis of different nutrients during digestion is shown.

(1) General review of the litterature and personnal contribution. 
The relative importance of the different proteolytic enzymes is summarised. The sensibility of chymotrypsin level in the pancreas was early demonstrated in the Rat. We found similar results in the pancreatic juice of the recently weaned pig which exhibit an increase of 2 to 3 times on a protein rich dict. The specific role of pancreatic amylase and intestinal maltase in the hydrolysis of a starch rich dict is consiclered.

Physiopathological disturbances have been found associated to a lack of enzyme in the small intestine. Some recent reports indicate a very low level of pancreatic amylase associated with arrival diarrhoea as well as acute gastroenteritis of the recently weaned piglets.

The third chapter is a summary of the nutritional significance of the enzymes.

We found generally in early weaned pigs an improvement of the apparent digestibility of soybean protein and fish meal protein with the age (Combs, 't al., I963). The same results are observed with raw starch or maltose. Some considerations are made about the effect of an enzyme supplementation of the starter, and on the comparison of steamed starch and dextrin used as the whole source of carbohydrate.

Conclusions are drawn about the adaptation of the proteolytic and the glucolytic enzymes of the digestive tract of the young pig during the suckling and the weaning periods.

Considerations of the optimum age at weaning must be based on our physiological knowledge of the possible adaptation of the piglet to dry concentrated diet rich in starch.

\section{RÉFÉRENCES BIBLIOGRAPHIQUES}

Aumaitri A., 1965. Bases physiologiques du sevrage du Porcelet. Bull. Soc. Sci. Hyg. Alim., 53, I6oI77.

Avmaitre A., r967. Étude de la dégradation enzymatique de divers amidons par le suc pancréatique de porcelet en cours de sevrage. Proc. l'II' Congrès Intern. Nutr. Hamburg (1966), 5, Ioo-Io3, Pergamon Press Ltd.

Aumaitre A., Rérat A., 1966. Données non publićes.

Aumaitre A., Ŕ́rat A., I968. Digestive enzymes in piglets during weaning : Pancreatic lipase.

Sess. 7, Cont. Pap. 83. Proc. 2nd World. Conf. Anim. Prod., university of Maryland $3^{8 \mathrm{I}}$.

Aumaitre A., Joundet C., Salmon-I.egagneur E., r964. Étude des activités amylolytiques chez le Porcelet en cours de sevrage. Ann. Zootech., 13, H.-S., 55-74.

BAILEY C. B., KitTs W. D., Woods A. J., I956. The development of the digestive enzyme system of the pig during its preweaning phase of growth. B. Intestinal lactase, sucrase and maltase. Canad. J. Agri. Sci., 36, 5 I-58.

Bjecker I). E., Cllirey I). E., Terrill S. W., I954, Comparison of carbohydrate in synthetic milk diet for the baby pig. Arch. Biochem. Biophys, 48, I78-183.

13ex Abdeljlil A., Visani A., Desnuelle P., I963. Adaptation of the exocrine secretion of rat pancreas to the composition of the diet. Biochem. Biophys. Res. Comm., 10, I12-I 6 .

Ben Abdeljlil A., Desncelle P., ig64. Sur l'adaptation des enzymes exocrines du pancréas à la composition du régime. Biochem. Biophys. Acta, 81, i $36-149$.

Bierry H., Terroine E. F., i905. Sur la maltase du suc pancréatique de sécrétine. C. R. Acad. Sci., Paris, 141, I46-I47.

Bovman J. G., Jansen W., IME LEEUW A. H., r969. Jisaccharides activity in the small intestine in healthy pigs and in piglets suffering from white scour. Tijdschar. Diergeneesk, 94, 454-46.

Braude R., Dollar A. M., Mitchell K. G., Porter J. W. G., I958. Proteolytic enzymes and the clotting of milk in the stomach of the young pig. Proc. Nutr. Soc., 17, XLIX-L.

BURnetT G.S., Neil E. L., I964. The influence of processing and of certain crude enzyme preparations on the utilization of cereals by pigs. Anim. Prod, 6, 237-244.

Calder A. I'. C., Iodge (x. A., Blair R., I959. The early weaning of pigs. V. The inclusion of digestive enzymes and antibiotics in diets for pigs weaned at 6-7 lb., live weight. J. A gric. Sci., 53, I30-I35.

Colombus A., Gobel. G., I958. Der Einfluss eines Enzyme-Preparates auf die Futterverwertung nach Versuchen an waschsendem Gefugel. Jahrb. Arbeitsgemeinschaft Füterungsberatung, 2, 25 I-257.

Combs G. E., Alsmeyer W. L., Wallace H. I., Koger M., ig6o. Enzyme supplementation of baby pig rations containing different sources of carbohydrate and protein. J. Anim. Sci., 19, 392-397.

Combs (i. E., Osegueda li. L., Wamace H. D., Ammerman C. J3., I963. Digestibility of rations containing different sources of supplementary protein by young pigs. J. Anim. Sci., 22, 396-398.

Corring T., Atmattre., i97o. Mise en place de l'équipement enzymatique du pancréas exocrine du jeune rat pendant la période embryonnaire, d'allaitement et le sevrage. Ann. Biol. anim. Bioch. Biophys., 10, 43I-44I.

Cunvishas H. M., I959. Digestion of starch and some of its degradation products by newborn pigs. J. Anim. Sci., 18, 964-974. 
Cunningham H. M., Brisson J. G., 1957. The effect of amylases on the digestibility of starch by baby pigs. J. Anim. Sci. 16, 370-376.

Dahlguist A., 1960. Hog intestinal alpha-glucosidases: solubilization, separation and characterization. Thesis, Akademisk Avhandling Lund.

Dahlouist A., r96r $a$. The location of carbohydrases in the digestive tract of the pig. Biochem. J., 788, $282-288$.

DAHLQuist A., Ig6I $b$. Intestinal carbohydrases of a new born pig. Nature, 190, 31-32.

Dahlouist A., 1963. Separation and characterization of two rat intestinal amylases. Biochem. $J$., 89, 272-275.

Desnuelle P., I96r. Digestion, absorption intestinale et transport des glycérides chez les animaux supérieurs. Coll. Inter., Marseille, 35-54. C. N. R. S. Paris.

Dollar A. M., Mitcheld K. G., Porter J. W. G., I957. The utilization of carbohydrates in the young pig. Proc. Nutr. Soc., 16, XII-XIII.

Frazer A. C., I943. Lipolysis and fat absorption. J. Physiol, 102, 329-333.

Gomez J. A., Supnet M. G., Puyadan R. B., Rigor E. M., ig65. The effect of enzyme supplementation of a starter ration on baby pigs. Philipp. Agric., 48, 373-380.

Guilbot A., I968. Structure de l'amidon. Dégradation enzymatique. In Progrès en chimie agricole ei Alimentaire. Hermann ed., Paris, II5 p.

Hartman P. A., Hays V.W., Baker R. O., Neagle L. H., Catron D. V., ig6r. Digestive enzyme development in the young pig. J.Anim. Sci., 20, II4-123.

Hays V.W., Speer V.C., Hartman P. A., Catron D. V., I959. The effect of age and supplemental amino acids on the utilization of milk and soya protein by the young pig. J. Nutr., 69, I79-186.

Howard F., YUDKIN S., I963. Effect of dietary change upon the amylase and trypsin activities of the rat pancreas. Brit. J. Nutr., 17, 28I-295.

Hudman D. B., Friend D. W., Hartman P. A., Ashton G. C., Catron D. V., ig57. Digestive enzyme of the baby pig. Pancreatic and salivary amylase. J. A gric. Food. Chem., 5, 691-693.

Jensen L. S., Fry R. E., Allrer J. B., McGinnis J., I957. Improvement in the nutritional value of barley for chicks by enzyme supplementation. Poult. Sci., 36, 919-92 I.

Josefsson L., LINDBERG T., 1965. Intestinal dipeptidases. II. Distribution of dipeptidases in the small intestine of the pig. Biochem. Biophys. Acta, 105, I62-166.

Juhasz S., Tamasi G., Pesti L., 1967. Studies on some digestives enzymes in swine gastroenteritis. Acta Vet. Acad. Hungaricae, 17, 413-421.

Kitts W. D., Bailey C. 13., Woods A. J., 1956. The development of the digestive enzyme system of the pig during its preweaning phase of growth. A pancreatic amylase and lipase. Canad.J.Agric. Sci., 36, 46-50.

KolDovsky O., I966. The post-natal development of enzyme activities of the small intestine. In Development of Metabolism as velated to Nutrition, Karger ed. Basel, I77 P.

Koldovsky O., HaHN P., I964. The activity of amylase in homogenates of the pancreas of rats during early post-natal development. Physiol. Bohemos., 13, 288-29I.

Kulka R. G., Duksin D., I964. Patterns of growth and amylase activity in the developing chick pancreas. Bioch. Biophys. Acta, 91, 506-5r4.

LaRner J., MCNickle C. M., r95. Gastro-intestinal digestion of starch. I, The action of oligo I-6 glucosidase on branched saccharides, J. Biol. Chem., 215, 733-736.

Lévesque J., I955. Traitement des diarrhées du nourrisson. Doin Cie, éd. Paris, I92 pp.

Lewis C. J., Catron D. V., Iieu C. H., Speer V. C., Ashton G. C., I955. Enzyme supplementation of baby pig diets. J. Agric. Food. Chem., 3, I047-ro5o.

Lindberg T., I966. Studies on intestinal dipeptidases. Act. Physiol. Scand., 69, supp. 285, I-38.

Maner J. H., Pond W. G., Lowrey R. S., I959. Effect of proteolytic enzyme supplementation to stimulated-milk diets on weight gains and protein digestibility in baby pigs. J. Anim. Sci., 18, pp. I487.

Maner J. H., Pond W. G., Loosli J. K., Lowrey R. S., ig62. Effect of isolates soyabean protein and casein on the gastric $\mathrm{pH}$ and rate of passage of food residues in baby pigs. J. Anim. Sci., 21, 49-5r.

Neurath H., I964. Protein-digesting enzymes. Scient. Amer., 211, 68-79.

Pavlov I. P., I9I3. The work of the digestive glands. Charles Griffin ed., London.

Pekas J. C., Hays V. W., Thompson J. D., r96o. A mathod for the study of pancreatic secretion in the baby pig. J. Anim. Sci, 19, I333.

Pekas J. C., I96r. Development of exocrine secretion of the pancreas and nutrient utilization in the prenatal pig. Ph. D. Thesis Iowa State University.

Pekas J. C., Hays V. W., Thompson A. M., I964. Exclusion of the exocrine pancreatic secretion : effect on digestibility of soyabean and milk protein by baby pigs at various ages. J. Nutr., 82, $277-284$.

Pekas J. C., Thompson A. M., Hays V. W., I966. Characteristics of the exocrine pancreatic secretion of the young pig. J. Anim. Sci, 25, II3-I2 I.

RAdley J. A., 1953. Starch and its derivatives. Chapman and Hill, London. Vol. I, 5 Io pp.

Ramsey H. A., Young J. W., Wise G. H., I960. Effects of continuous nursing, length of the nursing 
period, and rate of milk consumption on the secretion of pregastric esterase by calves. J. Dairy Sci., 43, $1076-1083$.

Reboud J.-P., Ben Abderjlil A., Desnuelle P., i962. Variation de la teneur en enzymes du pancréas de rat en fonction de la composition des régimes. Bioch. Biophys. Acta 58, 326-337.

RÉrat ig62. (Communication personnclle).

SEwell R. F., West J. P., I965. Some effects of lactose on protein utilization in the baby pig. $J$. Anim. Sci, 24, 239-241.

Stwell R. I., Maxwell C. F., I966. Fffects of various sources of carbohydrate in the diet of early weaned pigs. J. Anim. Sci., 25, 796-799.

SNook J. T., r 965 . Dietary regulation of pancreatic enzyme synthesis section and inactivation in the Rat. J. Nutr., 87, 297-305.

Snook J. T., Meyer J. H., r964. Responses of digestive enzymes to dietary protein. J. Nutr. 82, 409-413.

WaLKer D. M., I959. The development of the digestive system of the young animal. II. Carbohydrase enzyme development in the young pig. J. Agric. Sci., 52, 357-37o.

Weijers H. A., VAn de Kamer J. H., I965. Alteration of intestinal bacterial flora as a cause of diarrhea Nutr. Abstr. Rev., 35, 59 I-604.

Yalovsky U., ZELIKSON R., KULKA G., I 969 . The effect of hydrocortisone on the accumulation of amvlase in embryonic chick pancreas. Febs. Letters $2,323-326$. 